\title{
MOOCs and OER in the Global South: Problems and Potential
}

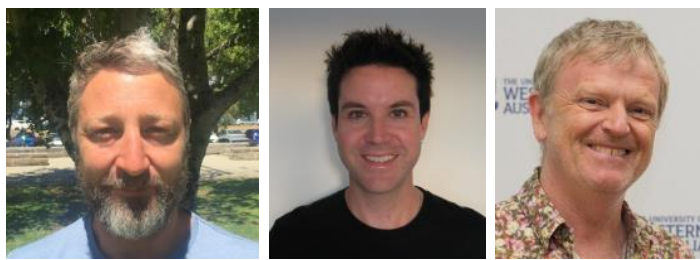

Monty King, Mark Pegrum, and Martin Forsey

The University of Western Australia

\begin{abstract}
This paper examines the problems and potential of Massive Open Online Courses (MOOCs) and Open Education Resources (OER) in the global South. Employing a systematic review of the research into the use of open online learning technologies in Southern contexts, we identify five interrelated themes emerging from the literature: 1) access to the Internet; 2) participant literacies; 3) online pedagogies; 4) the context of content; and 5) the flow of knowledge between North and South. The significance of Southern voice and participation is addressed in the final section, which concludes that on balance, the literature offers a qualified endorsement of the potential and actualities of MOOCs and OER in the global South. The ongoing tendency for the research literature to pay little heed to the agency of the social actors with the most to gain from these innovations is noted, opening up space for further research into the lived experience of online learners in the global South.
\end{abstract}

Keywords: online learning, MOOCs, OER, global South, international education 


\section{Introduction}

The post-2015 global educational development agenda, outlined in the United Nations Sustainable Development Goal (SDG) 4, is to "[e]nsure inclusive and quality education for all and promote lifelong learning" (United Nations General Assembly, 2015, para. 4). A 2014 UNESCO report on the Education For All (EFA) goals states that "[f]lexible lifelong and life-wide learning opportunities should be provided through formal, non-formal and informal pathways, including by harnessing the potential of ICTs [Information and Communication Technologies] to create a new culture of learning" (UNESCO, 2014, p.4). Questions arise as to whether a "culture of learning" can be fostered in the global South using Massive Open Online Courses (MOOCs) and Open Education Resources (OER). In seeking to articulate the actual and possible opportunities MOOCs and OER can provide in Southern contexts, we pose two research questions:

- What are the key problems restricting the uses of MOOCs and OER for learners in the global South?

- What potential exists for MOOCs and OER to provide educational opportunities for these learners?

\section{MOOCs, OER, and the Global South}

MOOCs exploded into public consciousness in 2012 (Billsberry, 2013) and have come to dominate much of the recent discourse on online learning. Industry leaders such as Koller (2012) and Agarwal (2014) have highlighted the potential for learners in the global South to benefit from MOOCs offered by prestigious universities in the North, but critics have dismissed these claims as being variously exaggerated (Daniel, 2012), impractical (Liyanagunawardena, Williams, \& Adams, 2013), absurd (Sharma, 2013), and neocolonial (Altbach, 2014). MOOCs have quickly evolved into a number of forms with various taxonomies proposed. For example, connectivist MOOCs (cMOOCs) are open-access and use Web 2.o technologies, such as blogs and wikis, to share user-generated content, producing openended outcomes for the participants (McAuley, Stewart, Siemens, \& Cormier, 2010). Platforms such as P2PU and Canvas Network exhibit cMOOC principles, creating open learning communities. Extended MOOCs (xMOOCs), made famous by Coursera and EdX, typically contain short videos, automated quizzes, peer-marked assessments, and online discussion forums. Their platforms allow course providers to use learning analytics to track participants' online activities, with potential benefit for both course producers and consumers, but with problematic ethical implications (boyd \& Crawford, 2012).

OER are defined as "digitised materials offered freely and openly for educators, students and selflearners to use and re-use for teaching, learning and research” (Hylén \& Schuller, 2007, p. 3). Examples of OER producers include the Khan Academy and OpenCourseWare (OCW) from the Massachusetts Institute of Technology (MIT), offering open online access to course content. Some authors include MOOCs under the OER umbrella (Rhoads, Berdan, \& Toven-Lindsey, 2013); others believe MOOCs to be a progressive step in the evolution of OER (Boga \& McGreal, 2014).

The global South is a term encompassing older designations such as "Third World" and "developing countries." Drawing on the work of social theorists such as Raewyn Connell, the global South refers to 
"regions outside Europe and North America that are mostly (though not all) low-income and often politically or culturally marginalized" (Dados \& Connell, 2012, p.12). In this review, the global South includes the countries of Latin America, Africa, Asia, and Oceania, but excludes Australia and New Zealand.

\section{Methodology}

Academic research on MOOCs and OER in Southern contexts was sourced by conducting searches of Scopus, Web of Science, the Education Resources Information Centre (ERIC), and Google Scholar databases in February 2017, using the terms "MOOCs" OR "OERs" AND ("global South" OR "developing countries" OR "developing world" OR "LDCs" [a term often used by the UN denoting Least Developed Countries] OR "low and middle income countries" OR "third world" [a term with limited contemporary currency]). Scopus returned 34 citations, Web of Science 15, and ERIC 18. Google Scholar returned over 8000 citations, reflecting the breadth of its search range; the first 120 citations were included before the results had minimal relevance.

Of this total of 187 citations, 38 were excluded as duplications, 36 were excluded due to their nonacademic or "gray" nature, including blogs and blog posts, unreferenced newsletter posts, abstracts, speech transcripts, slides, and letters to journal editors. A further 17 citations were excluded for their limited relevance to the review topic, leaving 96 citations as the basis of this review.

The sources were coded according to the problems and potential for MOOCs and OER in Southern contexts, resulting in the emergence of five major themes:

1. Access to the Internet,

2. Participant literacies,

3. Online pedagogies,

4. The context of content, and

5. The flow of knowledge between North and South.

These themes frame the results of the review below.

\section{Results}

\section{Access to the Internet}

An obvious barrier to open online learning is the ability of learners in the global South to access the Internet, particularly due to infrastructure limitations (Chadaj, Allison, \& Baxter, 2014; Christensen \& Alcorn, 2014; Godwin-Jones, 2014; Literat, 2015; Patru \& Ventakatamaran, 2016; Wang \& Jong, 2016; Wilson \& Gruzd, 2014). Examples of Internet access issues inhibiting MOOC and OER uptake are cited 
in Bangladesh and Sri Lanka (Hatakka, 2009); Cuba, Guatemala, and Peru (Garrote, Pettersson, \& Christie, 2011); Egypt (Aboshady et al., 2015); India (Chatterjee \& Nath 2014a; Perryman \& Seal 2016); Liberia (Madaio, Grinter, \& Zegura, 2016); Mexico and Thailand (Yáñez, Nigmonova, \& Panichpathom, 2014); Nigeria (Omonhinmin, Olopade, Afolabi, \& Atayero, 2015); Rwanda (Nkuyubwatsi, 2013); and Tanzania (Mtebe \& Raisamo, 2014).

Learners in rural areas are often underrepresented in MOOC participation figures in Southern countries (Alcorn, Christensen, \& Kapur, 2015; Christensen et al., 2013; Quinn \& Robinson, 2015) and access can be restricted by factors such as intermittent power supply and limited transport to locations with computers (Liyanagunawardena et al., 2013). The same authors also report a clear gender divide, with women often facing structural, gendered, "offline" barriers to access (Perryman \& de Los Arcos, 2016). People living with disabilities in the global South also face considerable accessibility barriers (Altimay et al., 2016). Arslan, Bagchi, and Ryu (2015) find a positive correlation between regional bandwidth strength and MOOC certification numbers.

Another key access barrier is the large amount of data required to download learning content (Daniel, Cano, \& Cervera, 2015; Larson \& Murray, 2008; Nkuyubwatsi, 2013). Most MOOC and OER sites require a bandwidth far higher than that available to many Southern learners, and the gap is growing (Escher, Noukakis, \& Aebischer, 2014; Haßler \& Jackson, 2009). Southern learners may also have difficulty using online collaborative tools within courses (Warusavitarana, Dona, Piyathilake, Epitawela, \& Edirisinghe, 2014).

Local learning hubs (Escher et al., 2014; Godwin-Jones, 2014) or acess hubs (Oyo \& Kalema, 2014) provide physical spaces with Internet-connected computers for learners to access online resources. Other ways of improving access include the use of low-resolution video content (Liyanagunawardena et al., 2013), audio files and transcripts (Haßler \& Jackson, 2009; Richter \& McPherson, 2012), promoting off-peak bandwidth usage (Daniel \& West, 2006), leveraging cloud-based technology (Jobe, 2013; Nabil, 2013), and making resources downloadable for use offline (Daniel et al., 2015) via Universal Serial Bus devices (USBs; Garrote et al., 2011).

For many in the global South, the growth of mobile ICTs for learning (mobile learning, or m-learning) can significantly increase access (Castillo, Lee, Zahra, \& Wagner, 2015; Godwin-Jones, 2014; Ibáñez \& Traxler, 2016; Wildavsky, 2014; Yáñez et al., 2014). Examples include:

- The New Economy Skills for Africa Program-ICT (NESAP-ICT) in Tanzania, which uses mlearning in combination with MOOC content to teach IT skills (Boga \& McGreal, 2014); and

- The SocialEDU program in Rwanda, which uses a MOOC platform with mobile-compatible content (Wildavsky, 2015), with integrated social media allowing easier access to MOOC discussions (Patru \& Ventakatamaran, 2016).

Analysis of the backgrounds of Coursera MOOC participants (Christensen et al., 2013) reveals that 14.8\% are from Brazil, Russia, India, China, or South Africa (BRICS) and 19.9\% from other developing countries. MOOC completers are already university-educated, revealing a widening educational divide between the global North and South, and also within Southern countries (Yáñez et al., 2014). More recent research reveals higher completion rates among participants from Southern countries (Garrido et al., 2016), although this is disputed (Kizilcec, Saltarelli, Reich, \& Cohen, 2017). Reach does not always 
equal accessibility (Nti, 2015), and many learners in the global South still struggle to utilise the necessary ICTs via a regular, stable Internet connection.

\section{Participant Literacies}

Learners need a range of literacies to benefit from MOOCs and OER, particularly in countries with an underdeveloped education system (Liyanagunawardena et al., 2013; Wilson \& Gruzd, 2014). Resources in English can help learners looking to improve their English language proficiency (Ally \& Samaka, 2013). Conversely, English-only content marginalises speakers of other languages (Oates, 2009; Sapargarliyev, 2015) and Southern learners may have difficulty understanding different accents and dialects, as well as technical and academic vocabulary (Nti, 2015).

A language audit of MOOCs created between 2012 and 2015 estimated that 75\% of MOOCs are produced in English; however, there is evidence of growing diversity (Stratton \& Grace, 2016). MOOCs are now presented in Arabic (Adham \& Lundqvist, 2015; Castillo et al., 2015), Chinese (Godwin-Jones, 2014; Liyanagunawardena \& Williams, 2014), and Spanish throughout Latin America (Valentin, 2015), in addition to courses in less common local languages (Varghese, 2016). Crowd-sourced translation, such as Coursera's Global Translator Community (GTC), has broadened MOOCs' international reach (Daniel et al., 2015; Godwin-Jones, 2014), and OER repositories such as Temoa provide a range of resources in multiple languages (Gómez-Zermeño \& Alemán Lorena de la Garza, 2015).

Many Southern leaners need basic computer literacies to use a keyboard, screen, and mouse (Daniel et al., 2015), particularly those living with disabilities (Altimay et al., 2016), and participants need skills to use the online tools required (Chen, 2013; Liyanagunawardena et al., 2013; Warusavitarana et al., 2014). Mobile ICTs have the advantage of being familiar to many users, without learners needing to understand the workings of a desktop computer (Boga \& McGreal, 2014), but resources such as cMOOCs require participants to interact across different digital spaces (Literat, 2015 p. 1170) while managing large amounts of information (Liyanagunawardena \& Williams, 2015). Preparatory MOOCs (Liyanagunawardena et al., 2013) or face-to-face workshops for OER users ( $\mathrm{Hu}, \mathrm{Li}, \mathrm{Li}, \&$ Huang, 2015) could aid literacy development.

\section{Online Pedagogies}

The pedagogical foundations of MOOCs and OER are central to their success in providing quality learning opportunities. Many MOOC formats may simply repackage old, didactic pedagogies (Chadaj et al., 2015; Onah, Sinclair, Boyatt \& Foss, 2014), and "freemium" xMOOC models, where basic content is free but premium features cost extra, can result in sub-optimal experiences for Southern learners (Kalman, 2014). Observers have noted a shift from teacher- to learner-centred pedagogy in OER (Kanwar, Kodhandaraman, \& Umar, 2010), while some suggest that MOOCs need to encourage more problem-based (Ally \& Samaka, 2013; Maitland \& Obeysekare, 2015) and project-based learning (Nkuyubwatsi, 2014).These approaches can, however, sometimes be met with resistance (Liyanagunawardena \& Williams, 2015), and participants may not trust new, unfamiliar online learning platforms (Garrido et al., 2016) or may be wary of commenting on course forums (Kizilcec et al., 2017; Onah et al., 2014).

The use of blended learning models, combining online resources with face-to-face interaction, is one means of maximising the educational potential of MOOCs (Cutrell et al., 2015; dela Pena Bandalaria \& Javier Alonso, 2015; Madaio et al., 2016; Wildavsky, 2015) and OER (Larson \& Murray, 2008; Mtebe \& 
Raisamo, 2014) in the global South. Nkuyubwatsi (2014) identifies benefits in local collaborative study groups, and the "meetup" function on some MOOC platforms encourages learner interaction offline (Bulger, Bright, \& Cobo, 2015). "MOOC camps" run by the U.S. State Department help learner groups to access courses while being mentored by English-speaking embassy staff (Godwin-Jones, 2014; Maitland \& Obeysekare, 2015; Wildavsky, 2014), similar to the MOOC+ model of peer-supported learning (Adams, Liyanagunawardena, Rassool, \& Williams, 2013).

Issues of certification and accreditation are closely linked to the pedagogy of open online content (Yáñez et al., 2014). A comparative study found that Kenyan students valued a MOOC credential more highly than their Swedish peers (Jobe, 2014), while participants in Colombia, the Philippines, and South Africa see MOOCs as a path to professional certification (Garrido et al., 2016). Without accreditation, Southern learners will be unable to convert MOOC learning into improved employment prospects (Daniel, 2012, as cited in Castillo et al., 2015).

Some argue that the MOOC model needs to be re-engineered if it is to provide a cost-effective means of educating a large and growing Southern learner cohort (Patru \& Ventakatamaran, 2016; Wildavsky, 2015). Examples of OER embedded within MOOC architecture includes:

- Open source, mobile ICT-compatible MOOC platforms using OER content to provide greater opportunities for Southern learners (Boga \& McGreal, 2014);

- The Creative Higher Education with Learning Object (partially abbreviated to CHiLO) in a mobile open learning environment designed for limited bandwidth access (Hori et al., 2015); and

- A proposed Mobile Assisted Language Learning (MALL)- MOOC for Continuing Professional Development (CPD) for language teachers (Ibáñez \& Traxler, 2016).

OER can be reused within different contexts (Liyanagunawardena et al., 2013), which has cost benefits for Southern resource producers (Mulligan, 2016); however, the initial expense of OER production can lead Southern countries to become net consumers of such resources (Leeds, 2013).

MOOCs and OER in Southern contexts have been designed or are proposed in agriculture (Hassen, 2013), computer science (Boga \& McGreal, 2014), disaster management (William, Elzie, Sebuwufu, Kiguli, \& Bazeyo, 2013), financial literacy (Siddike \& Kohda, 2016), healthcare (de Ruijter, Ferreira, \& Parsons, 2008; Liyanagunawardena \& Aboshady, 2017), library and information systems (LIS; Pujar \& Bansode, 2014; Pujar \& Tadasad, 2016), medicine (Aboshady et al., 2015; Liyanagunawardena \& Williams, 2014), and teacher training (Fyle, 2013). More research is needed into what pedagogical approaches work best across different disciplines in Southern contexts.

\section{Context of Content}

Contextualizing MOOC and OER content to local conditions is another important issue addressed in the literature. Local consultation is important when designing OER (Kanwar et al., 2010) and the use of generic resources can lead to higher participant dropout rates (Richter \& McPherson, 2012). Critics argue that MOOCs are designed for consumption, not for adaptation (Czerniewicz, Deacon, Small, \& Walji, 2014), and more consideration of local conditions and needs would benefit Southern learners (Castillo et al., 2015; Daniel et al., 2015; Nkuyubwatsi, 2014). 
Cultural differences among learners should be an important consideration for MOOC producers (Chen, 2013; Liyanagunawardena et al., 2013), and critics claim much existing content is inappropriate outside the global North (Wildavsky, 2014, 2015). A study of cultural translation in five Coursera MOOCs found that course content could be contextualized in two of the five courses, and discussion forums in all of the courses provided opportunities for learners to relate content to a personal context (Nkuyubwatsi, 2014), a central element of good course design (Liyanagunawardena \& Williams, 2015).

Richter and McPherson (2012) present an OER adaptation model, and resources have been successfully remixed in the Teacher Education in Sub-Saharan Africa (TESSA) programme (Connolly, Wilson, \& Wolfenden, 2007), and in a South African university (Mallinson \& Krull, 2015). A MOOC on the Ebola virus produced by MOOC platform Alison to raise awareness in affected countries (Liyanagunawardena \& Williams, 2015) demonstrates that these courses can target regional problems.

\section{The Flow of Knowledge From North to South}

The final theme to emerge from the literature concerns the North-South imbalances of knowledge flows in MOOCs and OER. Critics argue that the predominantly Northern origin of MOOCs represents academic nationalism, limiting the development of local academic culture (Altbach, 2014), or neocolonial paternalism (Godwin-Jones, 2014), which consolidates Northern hegemony (Czerniewicz et al., 2014), and threatens to create massive open educational homogeneity (Dumitrescu, 2015).

As key sites of learning and knowledge production, Southern higher education institutions (HEIs) need to lead the adaptation of existing MOOCs as well as the creation of new courses (Czerniewicz et al., 2014). Cox and Trotter (2016) discuss the challenges to OER adoption in South African universities, and highlight the importance of institutional culture in promoting or restricting OER production by academic staff. Barriers to MOOC and OER reuse in HEIs include copyright restrictions (Ncube, 2011) and lack of open access to scholarly publications (Anderson, 2013). Inter-university cooperation fosters Open Educational Practices (OEPs), which includes sharing OER and MOOC content (Patru \& Ventakatamaran, 2016). North-South knowledge partnerships have been developed between Malaysia and Australia (Valentin, 2015), and are proposed in Papua New Guinea (Woruba \& Abedin, 2015) and throughout Africa (Escher et al., 2014).

There are promising signs in the growth of OER production by some Southern countries (Ventakatamaran \& Kanwar, 2015). The Virtual University of Small States of the Commonwealth (VUSSC) produces OER and supports other Southern universities to do the same (Daniel, Kanwar, \& Uvalić-Trumbić, 2009). The University of the South Pacific's MOOC on climate change (Patru \& Ventakatamaran, 2016) and the University of the Philippines Open University (UPOU) MOOCs (dela Pena Bandalaria \& Javier Alonso, 2015) demonstrate the potential for course production in Southern countries.

There has been some caution around the wholesale adoption of OER within African HEIs due to further concerns of Northern academic elitism (Rambe \& Moete, 2016) and issues of access, required literacies and cultural barriers (Woldegiyorgis \& Carvalho, 2015). A survey of Chinese university students found almost 80\% had accessed some form of OER over the course of their studies (Hu et al., 2015), although production is limited to a small number of institutions (Xu, Zhang, \& Zheng, 2014). Projects incorporating locally produced or reused MOOCs and OER into university courses have been successfully instituted in India (Chatterjee \& Nath, 2014a, 2014b; Kamat, Keleher, Patil, \& Pujar, 2013; 
Nath \& Karmakar, 2014; Perryman, Buckler, \& Seal, 2014) and Pakistan (Abidi, Pasha, Moran, \& Ali, 2016; Pasha, Abidi, \& Ali, 2016). A Nigerian university has invested in online learning platforms using OCW from MIT (Omonhinmin et al., 2015), and a Value Focused Thinking model has been proposed for Caribbean HEIs to guide strategic MOOC adoption (Barclay \& Logan, 2013).

\section{Discussion}

Despite the numerous interacting structural barriers to MOOC and OER uptake detailed above, there is evidence to suggest that participation in open online learning in the global South is possible. MOOCs have demonstrated their potential to work at scale in Southern contexts (Laurillard \& Kennedy, 2017) and both MOOCs and OER are helping countries progress toward SDG 4 (McGreal, 2017). The fact that some MOOCs and OER have been successfully tested in South Asia, sub-Saharan Africa, and China, suggests that qualified endorsement is warranted. However, the literature also reveals problems previously identified in the discourse of participation in development.

One of the recurring themes within the participation literature is the use of the term 'top-down' both to criticise development initiatives and to explain their failure. It occurs time and again, in different epochs, reinforcing key ideals on which participation advocates depend. (Cornwall, 2006, p. 71)

We raise Cornwall's ideas about participation, based upon interrogation of development policy discourse regarding measures aimed at improving the lives of "the poor" over much of the $20^{\text {th }}$ century, to highlight two notable and closely related problems in the literature reviewed here. The first is the unreflexive focus on MOOCs and OER as either an obvious "public good" or as yet another ill thoughtthrough imposition upon peoples of the global South. This focus at best misses its targets, or at worst contributes to the ongoing reproduction of existing inequalities on global, regional, and national scales.

The second problem flows directly from the functionalist/criticalist dichotomy just highlighted in that the literature reflects an almost exclusive focus on the top-down, structural elements of MOOCs and OER. Given that the interwoven relationship between social structures and human agency is wellestablished as a sociological orthodoxy (Sayer, 1990), this sort of structural myopia is surprising. A number of authors argue that insufficient attention is paid to the desires, aspirations, and practices of those from the global South who are potential and/or actual participants in these online learning opportunities (Daniel et al., 2015; Garrido et al., 2016; Nti, 2015; Rhoads et al., 2013).

Cornwall's (2006) focus on the history of the idea of participation as continuing an unfulfilled trope of development policymakers serves to highlight, in her words, "the contingency of the normative ideals on which discourses of participation depend, which even the most trenchant of critics have left untouched" (p.79). In turn, this analysis serves to focus our attention on the ways in which development discourse all too often construes new developments as interventions imposed upon a lumpen mass of people at the end of a development pipeline. Even if construed as being ready to adopt the technologies of change, the potential and/or actual participants and consumers of MOOCs and OER are rarely brought into the picture. Exceptions include autoethnographic studies of MOOC participation (Liyanagunawardena, 2013; Nkuyubwatsi, 2013; Warusavitarana et al., 2014), and a study of archetypal Southern "learner personas" (Liyanagunawardena \& Williams, 2015), but a focus on the structural 
barriers to open online learning dominates the literature, to the exclusion of explorations of Southern learners as social agents.

What becomes clear from a systematic review of the literature is that more research is needed into the lived experiences of MOOC and OER users and potential users in the global South. This would help create insights into how they access and negotiate online learning environments within various structural constraints. Further, while the attempts of Northern countries to assist the South in improving education are laudable, more needs to be done to support Southern educators to create their own online resources in appropriate languages.

\section{Conclusion}

The key themes emerging from the research - access to the Internet, participant literacies, online pedagogies, the context of content, and the flow of knowledge between North and South - represent major barriers to MOOC and OER uptake in the global South. Despite the structural impediments, these forms of online learning have potential to meet at least some of the growing demand for education in the $21^{\text {st }}$ century. Prominent among developments assisting the spread of open online learning are the rapid increase in mobile ICT use worldwide, opportunities for blended learning, and MOOC models which incorporate OER content.

What is less well-known is how individual Southern learners negotiate these barriers to learning online, and the literature is poorer for it. At present, much of the research reproduces $20^{\text {th }}$ century top-down development thinking in the global North. The existing dominant mode of MOOC and OER production therefore needs rethinking, and Southern voices, those of both learners and educators, need to be heard. With further research into Southern learner and educator experiences, MOOCs and OER could create more learning opportunities which harness the educational potential of ICTs and the Internet. 


\section{References}

Abidi, S. H., Pasha, A., Moran, G., \& Ali, S. (2016). A roadmap for offering MOOC from an LMIC institution. Learning, Media and Technology, 42(4), 500-505. http://doi.org/10.1080/17439884.2016.1205601

Aboshady, O. A., Radwan, A. E., Eltaweel, A. R., Azzam, A., Aboelnaga, A. A., Hashem, H. A., ... Hassouna, A. (2015). Perception and use of massive open online courses among medical students in a developing country: Multicentre cross-sectional study. British Medical Journal Open, 5(1), 1-9. http://doi.org/10.1136/bmjopen-2014-006804

Adams, A., Liyanagunawardena, T. R., Rassool, N., \& Williams, S. (2013). Use of open educational resources in higher education. British Journal of Educational Technology, 44, E149-E150. http://doi.org/10.1111/bjet.12014

Adham, R. S., \& Lundqvist, K. O. (2015). MOOCs as a method of distance education in the Arab World - A review paper. European Journal of Open, Distance and E-Learning, 18(1), 1-13. http://doi.org/10.1515/eurodl-2015-0009

Agarwal, A. (2014, January 27). Why massive open online courses (still) matter [Video file]. Retrieved from https://www.ted.com/talks/anant agarwal why massively open online courses still ma tter?language $=$ en

Alcorn, B., Christensen, G., \& Kapur, D. (2015). Higher education and MOOCs in India and the global south. Change: The Magazine of Higher Learning, 47(3), 42-49. http://doi.org/10.1080/00091383.2015.1040710

Ally, M., \& Samaka, M. (2013). Open education resources and mobile technology to narrow the learning divide. The International Review of Research in Open and Distance Learning, 14(2), 14-27. Retrieved from http://www.irrodl.org/index.php/irrodl/article/view/1530/2479

Altbach, P. G. (2014). MOOCs as neocolonialism: Who controls knowledge? International Higher Education, 75(Spring), 5-7. https://doi.org/10.6017/ihe.2014.75.5426

Altimay, Z., Ossiannilsson, E., Kalac, M. O., Basari, G., Aktepebasi, A., \& Altmay, F. (2016). Establishing a framework on OER practices for ICT competence of disabled citizens. The Turkish Online Journal of Educational Technology, 15(3), 68-72. Retrieved from https://files.eric.ed.gov/fulltext/EJ1106370.pdf

Anderson, T. (2013). Open access scholarly publications as OER. International Review of Research in Open and Distance Learning, 14(2), 81-95. http://dx.doi.org/10.19173/irrodl.v14i2.1531

Arslan, F., Bagchi, K., \& Ryu, S. (2015, June). A Preliminary Evaluation of the determinants of certification success in MOOCs : A multi-level study. Paper presented at the Twenty-First Americas Conference on Information Systems. Retrieved from https://aisel.aisnet.org/amcis2015/ISEdu/GeneralPresentations/33/ 
Barclay, C., \& Logan, D. (2013, December). Towards an understanding of the implementation \& adoption of massive online open courses (MOOCs) in a developing economy context. Paper presented at the Special Interest Group for ICT in Global Development (SIG GlobDev) sixth annual workshop. Retrieved from http://www.globdev.org/files/proceedings2013/paper_21.pdf

Billsberry, J. (2013). MOOCs: Fad or revolution? Journal of Management Education, 37(6), 739-746. http://doi.org/10.1177/1052562913509226

Boga, S., \& McGreal, R. (2014). Introducing MOOCs to Africa: New economy skills for Africa program - ICT. Retrieved from http://oasis.col.org/handle/11599/613

boyd, d., \& Crawford, K. (2012). Critical questions for big data: Provocations for a cultural, technological, and scholarly phenomenon. Information Communication and Society, 15(5), 662-679. http://doi.org/10.1080/1369118X.2012.678878

Bulger, M., Bright, J., \& Cobo, C. (2015). The real component of virtual learning: Motivations for faceto-face MOOC meetings in developing and industrialised countries. Information, Communication and Society, 18(10), 1200-1216. http://doi.org/10.108o/1369118X.2015.1061571

Castillo, N. M., Lee, J., Zahra, F. T., \& Wagner, D. A. (2015). MOOCs for development: Trends, challenges, and opportunities. Information Technologies \& International Development, 11(2), 35-42. Retrieved from http://itidjournal.org/index.php/itid/article/view/1396

Chadaj, M., Allison, C., \& Baxter, G. (2014, October). MOOCs with attitudes: Insights from a practitioner based investigation. Paper presented at the IEEE Frontiers in Education (FIE) Conference. http://doi.org/10.1109/FIE.2014.7044101

Chatterjee, P., \& Nath, A. (2014a, December). Massive open online courses (MOOCs) in education - A case study in Indian context and vision to ubiquitous learning. Paper presented at the IEEE International Conference on MOOC, Innovation and Technology in Education (MITE). https://doi.org/10.1109/MITE.2014.7020237

Chatterjee, P., \& Nath, A. (2014b, December). Massive open online courses (MOOCs) in higher education - Unleashing the potential in India. Paper presented at the IEEE International Conference on MOOC, Innovation and Technology in Education (MITE). http://doi.org/10.1109/MITE.2014.7020283

Chen, J. C. (2013, August). Opportunities and challenges of MOOCs: perspectives from Asia. Paper presented at the International Federation of Library Associations and Institutions. World Library and Information Congress. Retrieved from http://library.ifla.org/157

Christensen, G., \& Alcorn, B. (2014). Are free online university courses an educational panacea? New Scientist, 221(2959), 24-25. http://doi.org/10.1016/So262-4079(14)60484-X

Christensen, G., Steinmetz, A., Alcorn, B., Bennett, A., Woods, D., \& Emanuel, E. J. (2013). The MOOC phenomenon: Who takes massive open online courses and why? Social Science 
Research Network Papers, 1-25. http://dx.doi.org/10.2139/ssrn.2350964

Connolly, T., Wilson, T., \& Wolfenden, F. (2007, September). Reaching the boundaries of the global south: Exploring the importance of guidelines for the localisation of OERs. Paper presented at Open Education 2007: Localizing and Learning, Logan, United States.

Cornwall, A. (2006). Historical perspectives on participation in development. Commonwealth \& Comparative Politics, 44(1), 62-83. http://doi.org/10.1080/14662040600624460

Cox, G., \& Trotter, H. (2016). Institutional culture and OER policy: How structure, culture, and agency mediate OER policy potential in South African Universities. International Review of Research in Open and Distance Learning, 17(5), 147-164. http://doi.org/10.19173/IRRODL.V17I5.2523

Cutrell, E., O’Neill, J., Bala, S., Nitish, B., Cross, A., Gupta, N., ... Thies, W. (2015, March). Blended learning in Indian colleges with massively empowered classroom. Paper presented at the Second Association of Computing Machinery (ACM) Conference on Learning at Scale. http://doi.org/10.1145/2724660.2724666

Czerniewicz, L., Deacon, A., Small, J., \& Walji, S. (2014). Developing world MOOCs: A curriculum view of the MOOC landscape. Journal of Global Litercies, Technologies, and Emerging Pedagogies, 2(3), 122-139. Retrieved from https://open.uct.ac.za/handle/11427/19562

Dados, N., \& Connell, R. (2012). The global south. Contexts, 11(1), 12-13. http://doi.org/10.1177/1536504212436479

Daniel, J. (2012). Making sense of MOOCs: Musings in a maze of myth, paradox and possibility. Journal of Interactive Media in Education, 36. http://doi.org/10.1145/2316936.2316953

Daniel, J., Cano, E. V., \& Cervera, M. G. (2015). The future of MOOCs: Adaptive learning or business model? Revista de Universidad y Sociedad del Concimiento (RUSC). Universities and Knowledge, 12(1), 64-73. http://doi.org/http://dx.doi.org/10.7238/rusc.v12i1.2475

Daniel, J., Kanwar, A., \& Uvalić-Trumbić, S. (2009). From Innocence to Experience: The politics and projects of cross-border higher education. In J. Fegan \& M. H. Field (Eds.), Education across borders: Politics, policy and legislative action (pp. 19-31). Netherlands: Springer. http://doi.org/10.1007/978-1-4020-9411-8_2

Daniel, J., \& West, P. (2006). From digital divide to digital dividend: What will It take? Innovate: Journal of Online Education, 2(5), n5.

de Ruijter, P., Ferreira, G., \& Parsons, R. (2008, May). Using educational technology to reach a wider audience for healthcare technology management. Paper presented at $5^{\text {th }}$ IET International Seminar on Appropriate Healthcare Technologies for Developing Countries, 2008. http://dx.doi.org/doi:10.1049/ic:20080586

dela Pena Bandalaria, M., \& Javier Alonso, G. (2015). Situating MOOCs in the developing world context: The Philippines case study. In C. J. Bonk, M. M. Lee, T. C. Reeves, \& T. H. Reynolds 
(Eds.), MOOCs and open education around the world (1st ed.; pp. 243-254). New York: Routledge.

Dumitrescu, V. M. (2015). The present-day trend towards massfication in higher education: The MOOC model. In I. Roceanu (Ed.), Rethinking education by leveraging the eLearning pillar of the Digital Agenda for Europe: Proceedings of the $11^{\text {th }}$ International Scientific Conference "eLearning and Software for Education" (eLSE) (pp. 135-142). Bucharest: Carol, NDU Publishing House.

Escher, G., Noukakis, D., \& Aebischer, P. (2014). Boosting higher education in Africa through shared massive open courses (MOOCs). In G. Carbonnier, M. Carton, \& K. King (Eds.), Education, learning, training: Critical issues for development (pp. 195-214). Leiden: Brill Nijhof. http://doi.org/10.1163/9789004281158_011

Fyle, C. (2013, June). Teacher education MOOCs for developing world contexts: Issues and design considerations. Paper presented at the Sixth International Conference of MIT's Learning International Networks Consortium (LINC). Retrieved from http://linc.mit.edu/linc2013/proceedings/Session3/Session3Fyle.pdf

Garrido, M., Koepke, L., Andersen, S., Mena, A. F., Macapagal, M., \& Dalvit, L. (2016). The advancing MOOCs for development initiative: An examination of MOOC usage for professional workforce development outcomes in Colombia, the Philippines, \& South Africa. Retrieved from https://digital.lib.washington.edu/researchworks/bitstream/handle/1773/35647/Advan cing MOOCs for Development Final Report 2016.pdf?sequence $=9$

Garrote, R., Pettersson, T., \& Christie, M. (2011). LiveUSB mediated education: A method to facilitate computer supported education. Australasian Journal of Educational Technology, 27(4), 619-632. https://doi.org/10.14742/ajet.941

Godwin-Jones, R. (2014). Global reach and local practice: The promise of MOOCs. Language Learning \& Technology, 18(3), 5-15. Retrieved from https://www.learntechlib.org/p/154108/

Gómez-Zermeño, M. G., \& Alemán Lorena de la Garza, Y. (2015). Temoa : An open educational resources portal to seek, investigate and inquire. Open Praxis, 7(3), 211-226. http://dx.doi.org/10.5944/openpraxis.7.3.211

Hassen, J. Y. (2013). The potential of a multimedia open educational resource module in enhancing effective teaching and learning in a postgraduate agricultural program: Experience from agshare project model. Journal of Asynchronous Learning Networks, 17(2), 52-62.

Haßler, B., \& Jackson, A. M. (2009). Bridging the bandwidth gap: Open educational resources and the digital divide. IEEE Transactions on Learning Technologies, Special Issue on Open Education Resources, 3(2), 1-8. http://doi.ieeecomputersociety.org/10.1109/TLT.2010.8

Hatakka, M. (2009). Build it and They Will Come? - Inhibiting factors for reuse of open content in developing countries. The Electronic Journal on Information Systems in Developing 
Countries, 37(5), 1-16. https://doi.org/10.1002/j.1681-4835.2009.tboo26o.x

Hori, M., Yamaji, K., Ono, S., Kita, T., Kobayashi, S., \& Yamada, T. (2015, October). CHiLO : Using an e-textbook to create an ad-hoc m- learning environment. Paper presented at the $45^{\text {th }}$ IEEE Frontiers in Education Conference (FIE). http://dx.doi.org/10.1109/FIE.2015.7344161

Hu, E., Li, Y., Li, J., \& Huang, W. H. (2015). Open educational resources (OER) usage and barriers: A study from Zhejiang University, China. Educational Technology Research and Development, 63(6), 957-974. http://doi.org/10.1007/s11423-015-9398-1

Hylén, J., \& Schuller, T. (2007). Giving knowledge for free: The emergence of open education resources. Paris: OECD Publishing. http://doi.org/10.1787/9789264032125-en

Ibáñez, A., \& Traxler, J. M. (2016). MALL-based MOOCs for language teachers: challenges and opportunities. Porta Linguarum, Monograph 1, 73-85. Retrieved from https://www.ugr.es/ portalin/articulos/PL monograph1 2016/art 6.pdf

Jobe, W. (2013). A Kenyan Cloud School. Massive open online \& ongoing Courses for blended and lifelong learning. Open Praxis, 5(4), 301-313. http://doi.org/10.5944/openpraxis.5.4.86

Jobe, W. (2014, October). No university credit, no problem? Exploring recognition of non-formal learning. Paper presented at the IEEE Frontiers in Education Conference (FIE).http://doi.org/10.1109/FIE.2014.7044389

Kalman, Y. M. (2014). A race to the bottom: MOOCs and higher education business models. Open Learning: The Journal of Open, Distance and E-Learning, 29(1), 5-14. http://doi.org/10.1080/02680513.2014.922410

Kamat, R., Keleher, P., Patil, A., \& Pujar, S. (2013, November). Promulgation of higher education in India : From university to meta university via massive open online courses (MOOCs). Paper presented at the International Engineering and Technology Education Conference. http://doi.org/10.13140/2.1.2552.9121

Kanwar, A., Kodhandaraman, B., \& Umar, A. (2010). Toward sustainable open education resources: A perspective from the global south. American Journal of Distance Education, 24(2), 65-80. http://doi.org/10.1080/08923641003696588

Kizilcec, R. F., Saltarelli, A. J., Reich, J., \& Cohen, G. L. (2017). Closing global achievement gaps in MOOCs. Science, 355(6322), 251-252. http://doi.org/doi:10.1126/science.aag2063

Koller, D. (2012, August 1). What we're learning from online education [Video file]. Retrieved from https://www.ted.com/talks/daphne koller_what we re learning from online education? language $=\mathrm{en}$

Larson, R. C., \& Murray, M. E. (2008). Open educational resources for blended learning in high schools: Overcoming impediments in developing countries. Journal of Asynchronous Learning Networks, 12(1), 85-103. 
Laurillard, D., \& Kennedy, E. (2017). The potential of MOOCs for learning at scale in the Global South. Retrieved from: http://www.researchcghe.org/publications/the-potential-of-moocsfor-learning-at-scale-in-the-global-south/

Leeds, B. (2013). Assessing the potential of OERs for ODL. South African Journal of Higher Education, 27(6), 1490-1507. Retrieved from https://hdl.handle.net/10520/EJC153339

Literat, I. (2015). Implications of massive open online courses for higher education: Mitigating or reifying educational inequities? Higher Education Research \& Development, 34(6), 11641177. http://doi.org/10.1080/07294360.2015.1024624

Liyanagunawardena, T. R. (2013). MOOC experience: A participant's reflection. SIGCAS Computers and Society, 44(1), 9-14. http://dx.doi.org/10.1145/2602147.2602149

Liyanagunawardena, T. R., \& Aboshady, O. A. (2017). Massive open online courses: a resource for health education in developing countries. Global Health Promotion, first published January 30, 2017, 1-3. http://doi.org/10.1177/1757975916680970

Liyanagunawardena, T. R., \& Williams, S. A. (2014). Massive open online courses on health and medicine: Review. Journal of Medical Internet Research, 16(8), e191. http://doi.org/10.2196/jmir.3439

Liyanagunawardena, T. R., \& Williams, S. A. (2015). Massive open online courses and perspectives from learners in developing countries. Vistas Journal of Humanities and Social Sciences, 9, 19-37. Retrieved from http://digital.lib.ou.ac.lk/docs/bitstream/701300122/1237/1/paper2.pdf

Liyanagunawardena, T. R., Williams, S., \& Adams, A. (2013). The impact and reach of MOOCs: A developing countries' perspective. eLearning Papers, 33, 1-8. http://doi.org/10.1016/j.jbusres.2007.11.013

Madaio, M. A., Grinter, R. E., \& Zegura, E. W. (2016, June). Experiences with MOOCs in a WestAfrican technology hub. Paper presented at the Eighth International Conference on Information and Communication Technologies and Development. http://doi.org/10.1145/2909609.2909633

Maitland, C., \& Obeysekare, E. (2015, May). The creation of capital through an ICT-based learning program: A case study of MOOC camp. Paper presentated at the Seventh International Conference on Information and Communication Technologies and Development. http://doi.org/10.1145/2737856.2738024

Mallinson, B. J., \& Krull, G. E. (2015). An OER online course remixing experience. Open Praxis, 7(3), 263-271. http://dx.doi.org/10.5944/openpraxis.7.3.195

McAuley, A., Stewart, B., Siemens, G., \& Cormier, D. (2010). The MOOC model for digital practice. Retrieved from https://oerknowledgecloud.org/sites/oerknowledgecloud.org/files/MOOC Final.pdf 
McGreal, R. (2017). Special report on the role of open educational resources in supporting the Sustainable Development Goal 4: Quality education challenges and opportunities. The International Review of Research in Open and Distributed Learning, 18(7). Retrieved from http://www.irrodl.org/index.php/irrodl/article/view/3541/4433

Mtebe, J. S., \& Raisamo, R. (2014). Investigating perceived barriers to the use of open educational resources in higher education in Tanzania. The International Review of Research in Open and Distance Learning, 15, 43-65. Retrieved from http://www.irrodl.org/index.php/irrodl/article/view/1803/2841

Mulligan, B. (2016). Lowering MOOC production costs and the significance for developing countries. In P. Kirby \& G. Marks (Eds.), Global learn 2016: Proceedings of the 2016 Global Conference on Learning and Technology (pp. 352-358). Limerick: Association for the Advancement of Computing in Education (AACE).

Nabil, S. (2013). Cloud computing and the web: Their potential disruption of the digital and education divide. In D. Vrontis, Y. Weber \& E. Tsoukatos (Eds.), Confronting Contemporary Business Challenges through Management Innovation: Proceedings of the 6th Annual Conference of the Euromed Academy of Business (pp. 2217-2236). Cascais: EuroMed Press

Nath, A., \& Karmakar, A. (2014). MOOCs Impact in higher education institution: A pilot study In Indian context. International Journal of Engineering Research and Applications, 4(7), 156163. Retrieved from http://ijera.com/papers/Vol4 issue7/Version\%203/AA04703156163.pdf

Ncube, C. B. (2011). Key copyright issues in African distance education: A South African case study. Distance Education, 32(2), 269-275.

Nkuyubwatsi, B. (2013). Evaluation of massive open online courses (MOOCs) From the learner's perspective. Paper presented at the 12th European conference on e-learning ECEL, Valbonne, France.

Nkuyubwatsi, B. (2014). Cultural translation in massive open online courses (MOOCs). eLearning Papers, 37, 1-10. Retrieved from https://lra.le.ac.uk/bitstream/2381/28554/4/In_depth_37_3.pdf

Nti, K. (2015). Supporting access to open online courses for learners of developing countries. International Review of Research in Open and Distance Learning, 16(4), 156-171. Retrieved from http://www.irrodl.org/index.php/irrodl/article/view/2328/3457

Oates, L. (2009). Coming up short in the OER movement: African language OERs. Access to Knowledge: A Course Journal, 1(2), 1-16.

Omonhinmin, C. A., Olopade, D., Afolabi, A., \& Atayero, A. A. (2015, January). Open education and digital scholarly communication in covenant university. Paper presented at 2014 International Conference on Web and Open Access to Learning. http://doi.org/10.1109/ICWOAL.2014.7009199

Onah, D. F., Sinclair, J., Boyatt, R., \& Foss, J. (2014, November). Massive open online courses: 
Learners participation. Paper presented at 7 th International Conference of Education, Research and Innovation (ICERI).http://doi.org/10.1007/s11576-014-0405-7

Oyo, B., \& Kalema, B. M. (2014). Massive open online courses for Africa by Africa. The International Review of Research in Open and Distributed Learning, 15(6), 1-13. http://dx.doi.org/10.19173/irrodl.v15i6.1889

Pasha, A., Abidi, S. H., \& Ali, S. (2016). Challenges of offering a MOOC from an LMIC. International Review of Research in Open and Distributed Learning, 17(6), 221228. http://dx.doi.org/10.19173/irrodl.v17i6.2696

Patru, M., \& Balaji, V. (2016). Making sense of MOOCs: A guide for policy-makers in developing countries. UNESCO and Commonwealth of Learning. Retrieved from http://unesdoc.unesco.org/images/0024/002451/245122E.pdf

Perryman, L.-A., Buckler, A., \& Seal, T. (2014). From global to local: Learning from TESS-India's approach to OER localisation across seven Indian states. OER14 Building Communities of Open Practice, 2014(2), 1-11. http://doi.org/10.5334/jime.af

Perryman, L.-A., \& de Los Arcos, B. (2016). Women's empowerment through openness: OER, OEP and the sustainable development goals. Open Praxis, 8(2), 16318o. http://dx.doi.org/10.5944/openpraxis.8.2.289

Perryman, L.-A., \& Seal, T. (2016). Open educational practices and attitudes to openness across India : Reporting the findings of the open education research hub pan-India survey. Journal of Interactive Media in Education, 1, 1-17. http://dx.doi.org/10.5334/jime.416

Pujar, S. M., \& Bansode, S. Y. (2014). MOOCs and LIS education: A massive opportunity or challenge. Annals of Library and Information Studies, 61, 74-78. Retrieved from http://op.niscair.res.in/index.php/ALIS/article/view/4511/102

Pujar, S. M., \& Tadasad, P. G. (2016). MOOCs - an opportunity for international collaboration in LIS education. New Library World, 117(5/6), 360-373. http://doi.org/10.1108/NLW-07-20150048

Quinn, S., \& Robinson, A. C. (2015, August). Mapping student engagement in a massive open online course (MOOC). Paper presented at the $27^{\text {th }}$ International Cartographic Conference $16^{\text {th }}$ General Assembly. Retrieved from https://icaci.org/files/documents/ICC proceedings/ICC2015/papers/22/559.html

Rambe, P. \& Moeti, M. (2016) Disrupting and democratising higher education provision or entrenching academic elitism: Towards a model of MOOCs adoption at African universities. Educational Technology Research and Development 65(3) 631-651. https://doi.org/10.1007/s11423-016-9500-3

Rhoads, R. A., Berdan, J., \& Toven-Lindsey, B. (2013). The open courseware movement in higher education: Unmasking power and raising questions about the movement's democratic potential. Educational Theory, 63(1), 87-109. http://doi.org/10.1111/edth.12011 
Richter, T., \& McPherson, M. (2012). Open educational resources: Education for the world? Distance Education, 33(2), 201-219. https://doi.org/10.1080/01587919.2012.692068

Sapargarliyev, D. (2015). Forced necessity: MOOCs in post-Soviet countries. In M. Ciussi (Ed.), Leading issues in elearning. MOOCs and flip: What's really changing? (pp. 23-29) Reading: Academic Conferences and Publishing Ltd. Retrieved from http://www.academicbookshop.com/ourshop/prod 3810239-Leading-Issues-in-eLearning-Research-MOOCs-andFlip-Whats-Really-Changing-Volume-2-ePUB-edition.html

Sayer, D. (1990). Reinventing the wheel: Anthony Giddens, Karl Marx and social change. In J. Clark, C. Modgil, \& S. Modgil (Eds.), Anthony Giddens: consensus and controversy (pp. 235-250). London: The Falmer Press.

Sharma, G. (2013, July 15). A MOOC delusion: Why visions to educate the world are absurd [Blog post]. Retrieved from http://chronicle.com/blogs/worldwise/a-mooc-delusion-why-visionsto-educate-the-world-are-absurd/32599

Siddike, A. K., \& Kohda, Y. (2016). Towards a service system for social innovation in education: A possible application of MOOCs. Knowledge Management \& E-Learning, 8(1), 124-137. Retrieved from https://doaj.org/article/ca7155b1525a4e67a219defo3daf7d96

Stratton, C., \& Grace, R. (2016). Exploring linguistic diversity of MOOCs : Implications for international development.Proceedings of the Association for Information Science and Technology, 53(1), 1-6. https://doi.org/10.1002/pra2.2016.14505301071

United Nations General Assemby (UNGA). (2015). Transforming our world: The 2030 Agenda for Sustainable Development (A/RES/70/1) [2015]). Retrieved from http://www.un.org/ga/search/view doc.asp?symbol=A/RES/70/1

United Nations Educational, Scientific and Cultural Organisation (UNESCO). (2014). Position Paper on Education Post-2015. Retrieved from http://unesdoc.unesco.org/images/0022/002273/227336E.pdf

Valentin, C. (2015). MOOCs global digital divide: Reality or myth? In F. Nafukho \& B. Irby (Eds.), Handbook of research on innovative technology integration in higher education (pp. 376397). Hershey PA: ICI Global.

Varghese, N. V. (2016). What changed after "peril and promise"? An analysis of higher education in developing countries. International Journal of African Higher Education, 3(1), 97-112. https://doi.org/10.6017/ijahe.v3i1.9639

Ventakatamaran, B., \& Kanwar, A. (2015). Changing the tune: MOOCs for human development? In C. J. Bonk, M. M. Lee, T. C. Reeves, \& T. H. Reynolds (Eds.), MOOCs and open education around the world (pp. 206-217). New York: Routledge.

Wang, T., \& Jong, M. S. Y. (2016). Towards equitable quality education for all: Are MOOCs really a way out? In Y.-T. Wu, M. Chang, B. Li, T.-W. Chan, S. C. Kong, H.-C. Lin, ... P. Li (Eds.), Conference proceedings of the 2oth Global Chinese Conference on Computers in Education 
(pp. 402-408). Hong Kong: The Hong Kong Institute of Education.

Warusavitarana, P. A., Dona, K. L., Piyathilake, H. C., Epitawela, D. D., \& Edirisinghe, M. U. (2014). MOOCs: A higher education game changer in developing countries. Rhetoric and Reality. Retrieved from http://www.ascilite.org/conferences/dunedin2014/files/fullpapers/321Warusavitarana.pdf

Wildavsky, B. (2014). Evolving Toward Significance or MOOC Ado About Nothing? International Educator, 23(3), 74-79. Retrieved from https://search-proquestcom.ezproxy.library.uwa.edu.au/docview/1525828294?accountid=14681\&rfr id=info\%3Axri \%2Fsid\%3Aprimo

Wildavsky, B. (2015). MOOCs in the developing world: Hope or hype? International Higher Education, 8o, 23-25. http://dx.doi.org/10.6017/ihe.2015.80.6154

William, L. R., Elzie, D., Sebuwufu, D., Kiguli, J., \& Bazeyo, W. (2013). Opportunities for strategic use of e-learning in scaling up disaster management capacity in Eastern Africa: A descriptive analysis. East African Journal of Public Health, 1O(2), 403-409. Retrieved from https://www.ajol.info/index.php/eajph/article/view/109115

Wilson, L., \& Gruzd, A. (2014). MOOCs - International information and education phenomenon? Bulletin of the Association for Information Science \& Technology, 40(5), 35-40. http://doi.org/10.1002/bult.2014.1720400510

Woldegiyorgis, A. A., \& Carvalho, L. (2015). Massive open online courses (MOOCs) and the "revolution" in higher education: Implications for Africa. Paper presented at the 13th international conference on African private higher education (pp. 321-341). Addis Ababa, Ethiopia.

Woruba, R., \& Abedin, B. (2015, June). Investigating massive open online courses (MOOCS) opportunities for developing countries: Case of Papua New Guinea. Paper persented at Pacific Asia Conference on Information Systems (PACIS). Retrieved from https://aisel.aisnet.org/pacis2015/211/?utm source=aisel.aisnet.org\%2Fpacis2015\%2F211\& utm $\_$medium $=$PDF\&utm campaign=PDFCoverPages

Xu, L., Zhang, J., \& Zheng, Q. (2014). The landscape of Chinese open educational resources research. Campus-Wide Information Systems, 31(4), 230-241. http://doi.org/10.1108/CWIS-09-20130056

Yáñez, C. E. F., Nigmonova, D., \& Panichpathom, W. (2014). DeMOOCratization of education?: Massive open online courses (MOOCs) and the opportunities and challenges for developing countries. Graduate Institute of International and Development Studies, Geneva, Switzerland. Retrieved from https://repository.graduateinstitute.ch/record/286962/files/MOOCs_Full_Final.pdf 
King, Pegrum, and Forsey

Athabasca

University

(2) $\frac{0}{2}$ 